\title{
Disillusionment of Caulfield's Self-salvation in The Cather in the Rye
}

\author{
He Wei \\ Sichuan University of Arts and Science, Dazhou, China
}

\begin{abstract}
Holden Caulfield, hero of The Catcher in the rye, caught in spiritual crisis before getting into adult world. After leaving his boarding school, he chooses to wander in New York City, tries to find someone to be connected in order to save him from alienation and depression. However, the modern science expels "God", declaring the death of "Men", together with the disappearance of Free Will. Therefore, no matter how hard Caulfield want to escape his fate, he can not find a place in his society. Then he turns to ideal innocent children world, wishing to be their protector, only to find that he can not prevent the growth of live. Watching his sister Phoebe and other children in the carrousel, Caulfield finally realizes that growing is inevitable, and nobody has the ability to stop the passage of life.
\end{abstract}

Index Terms - The Cather in the Rye, absurdity, fate, free will, salvation

\section{INTRODUCTION}

Caulfield in the Catcher in the Rye feels alienated and depressed before entering into adult world. After being kicking out of his school, he chooses to wander in New York City, from place to place with a mission of find someone to be connected--to be his savior. However, the development of modern science declared the death of "God", thus is the disappearance of free will. So no matter how hard Caulfield tries, he still cannot escape his fate.

\section{The Death of Men}

In Greek Mythology, Sisyphus was a king punished in Tartarus by Zeus. Sisyphus or Sisyphos was the king of Ephyra. He was punished for his self-aggrandizing craftiness and deceitfulness by being forced to roll an immense boulder up a hill only for it to roll down when they near the top, repeating this action for eternity. (http://en.wikipedia.org/wiki/Sisyphus) Sisyphus was a common subject for ancient writers, and appeared in their works. Sisyphus was elevated to the status of an absurd hero by Albert Camus, a French absurdist, in an essay entitled The Myth of Sisyphus. After that, The Myth of Sisyphus became the representation of meaningless life for its fruitless repetition, thereafter our ancestor kept asking what was the meaning of their lives?

Back to primitive period of human history, they were strongly aware of their inferior position in the universe for their inability of controlling everything around. In the process of figuring out the mysteries of the world, they attributed those to different gods in their imagination. They showed their reverence to gods in charge of different powers. They crawled under the foot of those gods, hoping to have their power one day, which can partly explain the appearance of legends of different kind of heroes, the offspring of gods and ordinary people. They did not spare any magnificent words to speak highly of hero's incredible adventures, like Prometheus who steal fire from heaven to earth.In that period, people had deep faith in gods' almighty ability. Crucially, they believed whenever they got into trouble, there would be hero saving them from troubles.

However, with the development of society and especially the advancement of modern science, human beings found themselves not as humble as they thought to be. They were thrilled with the miracles they had achieved, which motivated them to unfetter themselves from the spiritual burden to enjoy the happiness on earth as much as possible. They learned to appreciate themselves, such as their beautiful bodies, which were tremendously promoted by the essence of the Renaissance ideals of Humanism. During this movement, human beings knew that they were not the humble creatures of God and were entitled to enjoy the things on earth. Many writers at that time spared no efforts to praise the beauty of human beings, which made humans discontent with their humbleness, so they even elevated themselves to the side of God.

Science replaced God as the source of human beings' strength to conquer the whole world, however, they gradually found the once-powerful science explain many problems in their lives. But without the once-spiritual support (God who was exiled by modern science and especially the doctrine of Darwinism), human beings felt themselves rootless and alienated. And the belief in heroes evaporated with the disappearance of God. In late 19th century, Nietzsche even proclaimed God is dead. What's more, the idea of "the death of men" was demonstrated in French literature in the 20th century, and there is no hero to whom human beings can attach their hope any more. The John Christopher by Romain Rolland became the last hero lingering in their mind. They can not help questioning all the things around them which led them to feel suspicious of even the meaning of their existence, as Camus(1955) once said in The Myth of Sisyphus, 
"In a universe that is suddenly deprived of illusions and of light, man feels a stranger. His is an irremediable exile... This divorce between man and his life, the actor and his setting, truly constitutes the feeling of Absurdity" (p. 102).

The feeling of absurdity towards not only themselves and even the existence of the whole universe is perfectly demonstrated by the plays in the theater of the absurd, "Cut off from his religion, metaphysical, and transcendental roots, man is lost; all his actions become senseless, absurd, useless" (M. H. Abrams, 2004, p.1). The plays by the Absurd Theater exposes the true living condition to the public,

"The whole human beings get into the world to suffer all in the world, though they did not know why they needed to, but no one could avoid his destiny whether it was meaningful or meaningless. There was no one can tell them why should they live in this universe, and how long need they suffer for all of those. Two world wars had destroyed the myth that human beings were always on the way of eternity, advancement and prosperity, which forced them to accept that they did not as powerful as they imagined to be, and they began to reconsider their living condition on the whole universe.” (Francis A. Schaeffer, C. Everett Koop MD, 1979, p. 124-125)

Samuel Beckett is a master in depicting this feeling. In his masterpiece Waiting for Godot, he presents the irrationalism, helplessness and absurdity of life by applying illogical plots and unusual stage methods. Waiting for Godot just shows dialogues between two tramps in as waster place, fruitlessly but hopelessly waiting for one mysterious person, Godot--a person who may come or not. There is no explanation of why they must wait for Godot, and even they don't know who Godot is or why they need to wait for him. Actually this play is a representation of the common living condition of the westerners in general, and Godot in the play somewhat signifies "God" whose existence is beyond their ken. These two tramps represent the feeling that all human beings are experiencing. Alienated in this cold universe, they do not know the meaning of their existence and can not help asking whether there is anything one can do.

Human beings find themselves in a dilemma, clearly aware of the absurdity of their existence and the unpredictability of their future. However, with nothing do and nowhere to go, the only thing they can do is to wait in this cold universe.

\section{UNDERGOING SYMBOLIC DEATH}

Free will is the ability to choose between different possible courses of action unimpeded (Hegeler, Edward C., 1910. p. 369) .This raises the question whether, and in what sense, rational agents exercise control over human being's actions, decisions, and choices. Indeed, whether human beings have free will or not is a hotly-discussed topic for many centuries.

Ancient Greeks were always in pursuit of explaining different natural phenomenon in the universe, in other words, how to understand the appearance of haps and mishaps in their lives? And there was one thing that caught their attention-- "fate." They believed that fatal sisters decided the occurrence of all things in their lives, which evolved into the doctrine of Determinism. However, they were also wondering the possibility of the coexistence of free will and determinism. Though they knew their lives were under the control their fate, they still hoped to make some choices freely. Sophocles, one great Greek dramatist, explored this question in his masterpiece Oedipus the King, which began with a prophecy from god that Oedipus's father refused to accept. He chose to abandon his own son in order to escape from his doomed fate, however, no matter how hard he tried to escape, the history went as the prophet said. The same happened to Oedipus, the new king. He refused to listen to god, but tried to use his own strength and wisdom to solve all the problems. He didn't send anyone to hear the oracle from Apollo, but tries to find the truth by himself: "After a painful search I found one cure" (Sophocles, 2007, p 80). When Tiresias, the prophet, refused to tell the truth, he cursed on prophet and even gods:

Did you rise to the crisis? Not a word,

you and your birds, your gods-nothing.

No, but I came by, Oedipus the ignorant,

I stopped the Sphinx! With no help from the birds,

the flight of my own intelligence hit the mark (Sophocles, 2007, p 449-453).

At the very end, Oedipus knew he could do nothing to change his doomed fate. No matter how he chose to deal with his life, there was no choice at all. The heroes in this play were just like the pawns on a chessboard -- no matter what they do to escape their destinies, they failed. Sophocles questioned the existence of free will by Oedipus the King, for everything would go as the determined course no matter what kind of choice you made.

When going to the Middle Ages, most people believed in Christianity, and firmly believed that their lives were determined by God. What they needed to do was to suffer all the pain passively. The church, the substitute of God, took control of every aspect of people's lives, which in fact left no possibility of free will. And the life perspective went to its extreme in the literary movement. Naturalism at the early part of the 20th century in America maintained human beings were under the total control of heritage and environment, because no matter how hard one tried to control his life, at the very end he would find his efforts turn out to be meaningless. In their eyes, human beings were just like a feather in the wind, drifting to a place who will never know. There seemed to be many choices available, but actually all things would go as the determined one, and one's different choices were just confined to a determined circle.

Caulfield, the hero in The Cather of the Rye, suffering from a series of spiritual crisis before entering the adult world. The he decides to change, stepping into a journey in New York City, from place to place, with a hope to find his savior. However, characters Caulfield encounters in the novel fail as saviors or teachers or role models, which only exacerbates 
his disconnection both from them and from his own inner self(Erica Lawrence, 2001, 54). Thus, failed to find a place in society, he turns back to ideal innocent children's world, and wishes to be the protector of the children in the field of rye where he can make up the regulations to protect them from suffering his fate. In his mind, it is the best for the children. But do children really want the protection that Caulfield is eager to provide?

Phoebe, his eleven-year-old sister, is not naive. She is intelligence and shrewd when it comes to the ways of the world (Erica Lawrence, 2001, 56). She can dance like adult, prefers "grown-up" movies like The 39 Steps, dreams of herself as a writer, speaks as an adult, and it is also her who give Caulfield consolation when he wondered in New York City. She shows her concern after knowing his being kicked out of school. Crucially, it is also she who forces Caulfield to confront his inability of facing reality: "You don't like anything that's happening" (Salinger, 2008, p.398). Phoebe's words lead Caulfield to take a serious attitude towards the question of what is the thing he likes, instead of just being obsessed with the love of innocence and the hatred of the phoniness in the real world. Actually, Caulfield is eager to communicate with others all the time, so he keeps on searching for someone to talk with. But no matter in school or on his way, there is no one who can really understand him. And this time it is also Phoebe, his little sister, who makes him to see the desire in his mind--the catcher in the rye. However, it is also Phoebe who makes Caulfield see how impractical his dream is, for salvation maybe is not the thing that children want. From Phoebe's remarks on the "The Doctor" event, her attitude towards the danger of life is revealed clearly:

He feels sorry for it, the doctor. That's why he sticks this blanket over her face and everything and makes her suffocate. Then they make him go to jail for life imprisonment, but his child that he stuck the blanket over its head comes to visit him all the time and thanks him for what he did. He was a mercy killer. Only, he knows he deserves to go to jail because a doctor isn't supposed to take things away from God (Salinger, 2008, p.391).

Different from Caulfield's efforts of looking for protection, Phoebe has the courage to confront the dangers in her life. Although she thinks the child will thank the doctor for ending his pain, at the same time she feels more than happy for sending him to jail as the punishment of taking God's position for ending one's life. Life is full of suffering and sometimes it is painful, but no human savior can be accepted because no one has the right to play the role of God. A child like Phoebe is willing to accept the dangers in their life, which is proved further from her action of correcting Caulfield's understanding of Burns's poem,

You know that song 'if a body catch a body comin' through the rye'? I'd like -"

"It's 'If a body meet a body coming through the rye'?" old Phoebe said. "It's poem by Robert Burns."

"I know it's a poem by Robert Burns."

She was right, though. It is "If a body meet a body coming through the rye." I didn't know it then, though (Salinger, 2008, p. 409).

For the conversation above, it is obviously that Phoebe shows her view of life by correcting Caulfield's understanding of this poem. Emphasizing the word "meet" not "catch" shows Phoebe's attitude towards her life--everyone meets each other as equals in the field of rye instead of someone being saved by another, who obviously refers to the human savior. Through this, it is also Phoebe who brings Caulfield out of this ideal world to meet the real world and see his misunderstanding of the real world, because the innocents are not in the situation as he thinks. The protection he is so eager to provide turns out to be unnecessary to them, which leads to Caulfield's conclusion that his idea of being the catcher in the rye is something crazy, though it is the only thing he wants to do.

In addition, during Caulfield's wandering in New York City, he sees many children skating in Central Park and walking on the street without adults' guidance. Though it seems dangerous in his eyes, they enjoy their life to a great extent. The strong belief of being the children's savior begins to collapses into pieces. He is totally at a loss and does not know where he belongs. He finds those children are out of his understanding, whom he once thought knew very well.

\section{UnDERGOING TREMENDOUS SPIRITUAL CRISIS}

After suffering a series of disillusionment--the first of searching a savior to guide him into the adult world, and next being the children's protector in the world created by him-- Caulfield is strongly aware of his alienation from the world. At the beginning of chapter 25, Caulfield is nearly at the brim of nervous breakdown, feeling surrounded by ugliness and phoniness, like the profanity on the walls of the museum and schools and the vulgar Christmas-tree delivery men. Especially after the contact with Mr. Antolini, who makes him clearly realize his state of being lonely and alienated in the universe. He can not find a place he belongs to. When wandering in the streets of New York, he even prays to Allie to make him disappear as the ducks, because Mr. Antolini makes Caulfield realize his disconnection with his environment. The real children's world or the ahead adult world are different from his ideal world. Realizing there is no shelter he could find from this real world anymore, the only thing for him is to escape from this suffocating environment. The only choice is the place far away from modern civilization--the west, the place in which their ancestors once found peace and support. He decides to escape New York to west,imaging living like his ancestor.

The vast west, far away from modern civilization, is a place Caulfield's ancestors could turn to for strength and help when feeling depressed, because in their eyes it is Mother Nature who can take care of them. This tradition can be traced back to the first settlers on this new continent. With the hope of getting away from the political prosecution at home, they got to this land by Mayflower in 1661. They were warmly welcomed by the native Indians who helped them 
to get settled in this vast land. In the following year, they got a harvest and survived in this land. This new land turned out to be their dream land in which they put all their passion and efforts. With the belief on this new land, they gained the confidence to build their new home. Like the New Adam; they spared no efforts to work hard. This high spirit was recorded in Walt Whitman's Leaves of Grass. Although later they met many problems in the process of development, even suffered the disillusionment of the dream of the Garden of Eden, there was always a place they could escape from for consolation, recovering from their suffering and gaining the strength to move on--the vast west.

Natty Bumppo in James Cooper's Letherstocking Tales is a typical guy who gets bored with the white civilized world, and then decides to head into the west inhabited by native Indians. Natty gets the chance to connect with the Mother Nature and enjoys the life free from the burden of modern society. More importantly, he nurtures a deep brotherhood with the Indians, from whom he learns to live in a natural way. Finally, he decides to stay in the forest to get close to Mother Nature. Henry David Thoreau is another typical guy looking for a new lifestyle by living alone in nature, outside the limits of institutional roles and of social norms and manners. Nature is always the source of their strength when they feel weak, sad and depressed.

Consequently, the vast remote west became the last shelter in Caulfield's mind. It is a place where he can get away from that phony world where he has no way but to adapt himself to the accepted standards of that society. Feeling alienated from society, Caulfield decides to go to west for a new life which echoes with their ancestors' belief in "mother nature"--the west can take care of you in a way that no one can. He asks Sally if she feels disgust of the city and its phonies: "You know something," he tells her, "You're probably the only reason I am in New York right now, or anywhere. If you weren't around, I'd probably be someplace way the hell off. In the woods or some goddam place" (Salinger, 2008, p.357). But Sally cannot really understand the desire in Caulfield's mind: "You can't just do something like that, in the first place, we're both practically children. We'll have oodles of time to do those things--all those things. I mean, after you go to college and all" (Salinger, 2008,p.358). Without experiencing what Caulfield has undergone, Sally cannot know how desperately Caulfield wants to find a place to begin his new life. She just gives a negative response to Caulfield's passionate suggestion.

However, the west is no longer the one in Caulfield's imagination. In the process of westward movement, the government encouraged the new immigrants to explore this new land as further as possible. Many of them went to explore their new home there with all of their passion, which was depicted in Willar Cather's My Antonia. The industrious settlers put forward their frontier further and further with the hope of a better life; they used their wisdom to change the environment for their need. Meanwhile, the once quiet and remote west was influenced by modern civilization, losing its once appearance.

Meanwhile, just as Phoebe makes Caulfield realize how impractical his dream of being the catcher is, it is also Phoebe who makes him stay in the real world. In fact there is nowhere he could go to live as he expects, and the real life is the thing he needs to face with whether he likes it or not. Just as Caulfield once used the hunting hat to protect himself from the rain for a while, but at last he can not escape being soaked:

I got pretty soaking wet, especially my neck and my pants. My hunting hat really gave me quite a lot of protection, in a way, but I got soaked anyway. I didn't care, though. I felt so damn happy all of a sudden, the way old Phoebe kept going around and around. I was damn near bawling, I felt so damn happy, if you want to know the truth. I don't know the truth. I do not know why. It was just that she looked so damn nice, the way she kept going around and around, in her blue coat and all. God, I wish you could've been there. (Salinger, 2008, p. 444).

Phoebe, together with other children's courage to confront their lives, enlightens Caulfield to go through his life in a different way. Nowhere can he get the ideal world, and nothing in the real world can protect him forever, neither him nor other children. As an ordinary human being in the world, what they can do is to try to deal with his life as bravely as he can. The sight of seeing many children grab for the golden ring exposes one thing to Caulfield that he can not deny--although life might be better if there was a catcher in the rye, no one can be the human savior for everyone, just equals in the real world. Moreover, while the children are willing to accept the dangers in their life at the risk of falling, during this process they also enjoy the happiness of life.

\section{CONCLUSION}

Feeling disconnected with people around and alienated from his society, Caulfield wants to be saved, however, his effort of looking for a savior failed. Then Caulfield wants to be other children's protector -- the catcher in the rye, only to find Phobe and other children do not need his protection. He gets out of his obsession with being the children's protector when watching Phoebe ride the carousel. The carousel reminds him of the Museum of Natural History, both of which stand for something unchangeable, always there in the same condition. The thing that changes is the person who goes to that place. The carousel stays the same while the children who ride it continue to grow older. This scene enlightens Caulfield that the thing from which he seeks consolation is temporary, and amounts to self-deception. Caulfield gradually comes to term with one reality--all the children must meet the problem of "falling," willing or unwilling, out of innocence and into adulthood. Caulfield does not have the ability to prevent them from doing it or to save them from it, just like no one can save him from becoming an adult. 


\section{REFERENCES}

[1] Camus, Albert. (1955). The Myth of Sisyphus, translated by Justin O’Brien, London: Penguin Classics Press. http://en.wikipedia.org/wiki/Sisyphus (accessed 02/03/2018)

[2] Francis A. Schaeffer \& C. Everett Koop MD. (1979). Whatever Happen to the Human Race? New Jersey: Fleming H. Revell Company, 1979.

[3] Hegeler, Edward C. (1910). The Monist, Vol. 20.Open Court.p.369. http://en.wikipedia.org/wiki/Free_will (accessed 02/03/2018).

[4] Lawrence, Erica. (2001). "Salvation and Rebirth in The Catcher in the Rye and The Bell Jar," The Osward Review: An International Journal of Undergraduate Research and Criticism in the Discipline of English: Vol. 1: Iss.1, Article 10, 50-63.

[5] M. H, Abrams. (2004). A Glossary of Literary Terms. Beijing: Foreign Language Teaching and Research Press.

[6] Salinger, J.D. (2008). The Catcher in the Rye. Nanjing: Yilin Express.

[7] Sophocles. (2007). Oedipus the King. Trans. Robert Fagles. Reading for Writing. Ed. William Ellis. Sichuan: Sichuan University Express.

He Wei was born in Sichuan, China in 1982. She received her master degree in Literature from Sichuan University, China in 2010. She is currently a lecturer in School of Foreign Department, Sichuan University of Arts and Science, Sichuan, China. Her research interests include English and American Literature. 